\title{
Reasons for Couples to Prefer Withdrawal Method
}

\author{
Geri Çekme Yöntemini Eşlerin Tercih Etme Nedenleri
}

\author{
Sinem BULDURUCU ${ }^{\mathrm{a}}$ Saadet YAZICI ${ }^{\mathrm{b}}$
}

\begin{abstract}
This study was conducted in order to determine the reasons why men and women choose the withdrawal method, one of the traditional methods in preventing pregnancy. The study sample was composed of married women aged 15-49 years (150) and their partners. The study was applied in the Süleymaniye Obstetrics and Gynecology Training and Research Hospital. Data required for the research was collected during three month period of time via questionnaires on women and men, and was prepared in the light of recent literature on this subject. While analyzing the data, we used percentage, average and chi-squared testing. It was discovered that women's knowledge on family planning methods was significantly higher than men's $(p<0.05)$. We found that there was a significant difference between men and women in terms of their reasons to choose withdrawal as a birth-control $(\mathrm{p}<0.05)$. The rate of the men who preferred withdrawal method $(33.3 \%)$ was founded to be significantly higher than women $(18 \%)(\mathrm{p}<0.05)$. Although women were significantly more conscious about family planning than men, men were the ones to decide the method to use.
\end{abstract}

Keywords: Midwifery, family planning methods, traditional methods, withdrawal method

Özet $\mathrm{Bu}$ çalışma; eşlerinin geleneksel yöntemlerden biri olan geri çekme yöntemini gebeliğin önlenmesinde tercih etme nedenlerini saptamak amacı ile gerçekleştirildi. Araştırmanın örneklemini 15-49 yaş grubu, evli kadınlar (150) ve eşleri (150) oluşturturdu. Araştırma Süleymaniye Doğum ve Kadın Hastalıkları Eğitim Araştırma Hastanesinde gerçekleştirildi. Araştırmanın verileri literatür bilgisi doğrultusunda oluşturulan kadın ve eşine ilişkin anket formları aracılığ 1 ile toplandı. Verilerin değerlendirilmesinde, yüzdelik, ortalama ve Ki-kare önemlilik testi kullanıldı. İstatistiksel anlamlılık ise $\mathrm{p}<0.05$ ile tanımlandı. Kadınların etkili aile planlaması yöntemlerini erkeklerden istatistiksel olarak anlamlı düzeyde daha fazla bildiği bulundu $(\mathrm{p}<0.05)$. Geri çekme yöntemlerini tercih etme nedenleri açısından eşler arasında istatistiksel olarak anlamlı fark olduğu saptandı ( $\mathrm{p}<0.05)$.Geri çekme yöntemini kimin tercih ettiği sorulduğunda, erkeklerde "benim tercihim" diyenlerin oranı (\%33.3) kadınlardan $(\% 18)$ anlamlı olarak fazla bulundu $(\mathrm{p}<0.05)$. Sonuç olarak aile planlaması yöntemleri konusunda kadınların erkeklerden daha bilinçli olduğu ancak kararı erkeklerin verdiği söylenebilir.

Anahtar Kelimeler: Ebelik, aile planlaması yöntemleri, geleneksel yöntemler, geri çekme yöntemi

Geliş Tarihi/Receved: 21.11.2015 Kabul Tarihi/Accepted 05.04.2015

${ }^{a}$ Uzman Ebe, sinembul@yahoo.com.tr, Süleymaniye Doğum ve Kadın Hastalıkları Eğitim Araştırma Hastanesi

${ }^{\text {b} Y a z ı s ̧ m a ~ A d r e s i / ~ C o r r e s p o n d i n g, ~ D o c ̧ . ~ D r . ~ s a a d e t y a z c @ y a h o o . c o m, ~ I ̇ s t a n b u l ~ U ̈ n i v e r s i t e s i ~ S a g ̆ l ı k ~ B i l i m l e r i ~}$

Fakültesi-Ebelik Bölümü Ruh ve Sinir Hastalıkları Hastanesi (Bahçe İçi) 34740Bakırköy / İstanbul-Turkey

Phone:90 212-4141500-40137 


\section{Introduction}

This is a descriptive and cross-sectional study conducted for exploring the reasons men and women use withdrawal as one of the traditional family planning methods. Despite modern family planning methods, traditional methods are still being used for preventing unintended pregnancy in both developed and developing countries ${ }^{1}$

According to the results of the studies conducted in different countries on the use of withdrawal method, usage rate of the method was $35 \%$ in Romania, $24 \%$ in Czechoslovakia, $17.5 \%$ in Italy, and $4 \%$ in England. ${ }^{1-3}$

According to Turkey Demographic and Health Survey (TDHS-2008) ${ }^{4}$ results, $73 \%$ of married women in Turkey still use a contraceptive method. Forty-six percent of women prefer modern methods while $27 \%$ prefer traditional methods. Withdrawal is the mostly preferred method among other traditional methods of contraception. When we examine the statistics on the use of withdrawal method in Turkey during the last 20 years, the usage rate was found to be as in the following: in 1988 25.7\%, in 1993 $26.2 \%$, in $199824.4 \%$, in $200326.4 \%$ and in $200826.3 \%$. $^{1-3}$

In the countries where family planning services cannot be implemented effectively, there are excessive birth-rates and high risk pregnancy; maternal mortality rates are also high in those countries. ${ }^{5}$

Maternal mortality ratio in Turkey is 28.5 per 100000 live births. ${ }^{6}$ In general $(61.6 \%)$ of maternal mortality are results of preventable factors. When that condition is taken into consideration, quality and effectiveness of reproductive health and family planning services are extremely important for our country.

Both domestic and foreign studies have showed that reproduction and fertility controlling methods are determined according to patriarchal traditions and this situation affects reproductive behaviors of women. ${ }^{1-4}$

For the success of family planning services, relevant healthcare personnel must be well-trained and work effectively. Midwives are the key personnel in reproductive health and family planning services and also have close relations with families. Therefore by making good use of their roles as educators and counselors in the fields of family planning services, midwives can achieve positive behavioral changes in individuals and ensure more people benefit from family planning services. ${ }^{7,8}$

Accordingly, this study was carried out to determine the reasons for men and women to use withdrawal as a traditional family planning method in Turkey.

\section{Material and Methods}

This is a descriptive and cross-sectional study. The study was carried out between 01.05.2010 and 31.07.2010 in the Süleymaniye Obstetrics and Gynecology Training and Research Hospital, after receiving approval from the Study Ethics Committee and relevant authorities of the institution.

During the 3 month period, women and partners who presented at the hospital for various reasons (gynecological examination, child examination, family planning unit) and reported their use of the withdrawal method for the last 6 months or longer were included in the sample.

Prior to the study, health personnel who worked at the polyclinics were informed about the study in order to reach partners who use withdrawal. Health personnel were requested to refer partners who reported the use of the withdrawal method to the Family Planning (FP) unit. Among the men and women who presented at the family planning unit, those willing to participate in the study were included in the sample. Some couples did not wish to take part in the study during the data collection process (20 couples). Their decision was respected and these couples were not included in the study. In addition, the researcher provided training about effective methods to the couples who presented at the family planning unit. 
The sample of the research was comprised of 150 women and their husbands who were randomly chosen among the men and women who came to family planning policlinic between the specified dates (01.05.2010-31.07.2010) for education and consultation, during the work hours of the researcher. research;

Criteria for participating in the

1. Being willing to take part in the research,

2. Women between 15-49 and their husbands,

3. Actively using the withdrawal method for 6 months,

4. Women and their husbands who had the capacity for comprehending and answering questions taken in the research.

Research data was collected via questionnaires. Questionnaire forms were prepared by the researcher in the light of relevant literature review. Questionnaires for women composed of 30 questions while the ones for men included 20 questions. Ten questions of women questionnaires were on socio-demographical characteristic of the family, those questions were asked only of women. In order to determine the understandability of the questionnaire form, 15 women and their husbands were selected for pre-application and questionnaires were edited according to the outcomes of preapplication.

Before presenting questionnaires to the participants, the researcher informed them about the aim of the study and took their oral consents. Questionnaires were completed by the researcher through face to face interviews. Questionnaires were filled in separately for men and women, and each took about 15 minutes. Since the questionnaires were separate for males and females, in order to prevent the two groups from being affected by each other and in order to provide an environment where they could answer the questionnaires more comfortably, the questionnaire was applied by accepting women first into the interview room and men later.

The question form was open ended and also included yes or no questions. No scale was used for data collection.

The question form which was administered to women consisted of 30 questions and the questionnaire administered to men consisted of 20 questions. Since common questions pertaining to the sociodemographic properties of the family (family structure, income, duration of marriage, social security, etc.) were included in the form administered to women, the number of questions in that questionnaire was greater. In order to make comparison easier, the other questions in the questionnaire were parallel.

The questionnaires used in the study consist of the following topics:

- Descriptive information about the women and their partners

- Obstetrics history for the women

- Knowledge of the men and women on the subject of family planning

- The history of the couple regarding the coitus interrupts method they use

- Reasons for the couple choosing the coitus interrupts method

We used SPSS for Windows 15.0 packaged software for assessing data. The data was assessed with percentage, average and Chi-Squared test. We used $\mathrm{p}<0.05$ for statistical significance.

\section{Results}

Then the research data was evaluated, the distribution of withdrawal usage by age, education and wanting another child was as in the Table 1. 
Table1. Age, education and wanting another child characteristics of couples to sex

\begin{tabular}{|c|c|c|c|c|c|c|}
\hline \multirow{3}{*}{$\begin{array}{l}\text { Age, education and } \\
\text { wanting another child }\end{array}$} & \multicolumn{4}{|c|}{ Sex } & \multirow[b]{3}{*}{$\chi^{2}$} & \multirow[b]{3}{*}{$\mathrm{P}$} \\
\hline & \multicolumn{2}{|c|}{ Female (n: 150) } & \multicolumn{2}{|c|}{ Male (n: 150) } & & \\
\hline & Number & $\%$ & Number & $\%$ & & \\
\hline Age & & & & & \multirow{6}{*}{$\begin{array}{c}27.655 \\
\mathrm{sd}: 4\end{array}$} & \multirow{6}{*}{.000} \\
\hline $24 \downarrow$ & 37 & 24.6 & 15 & 10.1 & & \\
\hline $25-29$ & 35 & 23.3 & 35 & 23.3 & & \\
\hline $30-34$ & 43 & 28.7 & 26 & 17.3 & & \\
\hline $35-39$ & 22 & 14.7 & 50 & 33.3 & & \\
\hline $40 \uparrow$ & 13 & 8.7 & 24 & 16.0 & & \\
\hline Education & & & & & \multirow{6}{*}{$\begin{array}{l}9.063 \\
\text { sd:4 }\end{array}$} & \multirow{6}{*}{.060} \\
\hline Illiterate- literate & 15 & 10.0 & 6 & 4.0 & & \\
\hline Elementary school & 53 & 35.3 & 43 & 28.7 & & \\
\hline Middle school & 31 & 20.7 & 32 & 21.3 & & \\
\hline High school & 33 & 22.0 & 37 & 24.7 & & \\
\hline University & 18 & 12.0 & 32 & 21.3 & & \\
\hline Wanting another child & & & & & \multirow{4}{*}{$\begin{array}{c}2.227 \\
\text { sd:2 }\end{array}$} & \multirow{4}{*}{.328} \\
\hline Yes & 34 & 22.7 & 33 & 22.0 & & \\
\hline No & 83 & 55.3 & 73 & 48.7 & & \\
\hline Not sure & 33 & 22.0 & 44 & 29.3 & & \\
\hline
\end{tabular}

When the distribution of men and women' age groups by age was compared, we found that there was a statistically significant difference between the two sexes $(\mathrm{p}<0.01)$.

When the distribution of men and women by educational background was compared, there was no significant difference between the two sexes ( $p>0.05)$.

It was also comprehended that $(\mathrm{F}$ : $22.7 \%$-M: $22.0 \%$ ) wanted more babies while (F: $55.3 \%-\mathrm{M}: 48.7 \%$ ) did not want another child.

When the employment case was evaluated, men and women with employment (F: 28.0\%-M: 94.0\%), without employment (F: $72.0 \%-\mathrm{M}: 6.0 \%$ ) was different.

Family structures of the men and women participating in the research were analyzed: $32.7 \%$ extended families, while $67.3 \%$ nuclear families. Also, $16.0 \%$ of these men and women did not have health insurance, while $84 \%$ of men and women benefitted from health insurance.

It was also found that $37.3 \%$ of women included in the sample had had two pregnancies, $26.7 \%$ of them three pregnancies, $18.7 \%$ one pregnancy, $16.7 \%$ of them four or more pregnancies; however, only one woman had no pregnancy yet.

Forty seven point three percent of these men and women had two children, $26.7 \%$ had one, $20.7 \%$ had three children and $5.3 \%$ of them had no children yet.

It was also comprehended that $(\mathrm{F}$ : $22.7 \%$-M: 22.0\%) wanted more babies while (F: $55.3 \%-\mathrm{M}: 48.7 \%$ ) did not want another child.

There was no significant difference between men and women regarding the knowing with cervical mucus, vagina douche and cervical palpation methods ( $p>0.05$ ); however, the ratio of women knowing calendar and breastfeeding methods was significantly higher compared to men $(\mathrm{p}<0.01)$. 
Table 2. Distribution of couples by sexes regarding knowledge on modern family planning methods $(\mathrm{N}=300)$

\begin{tabular}{|c|c|c|c|c|c|c|}
\hline \multirow[t]{3}{*}{ Modern family planning methods } & \multicolumn{4}{|c|}{ Sex } & \multirow{3}{*}{$\chi^{2}$} & \multirow{3}{*}{$\mathrm{P}$} \\
\hline & \multicolumn{2}{|c|}{ Female (n: 150) } & \multicolumn{2}{|c|}{ Male (n: 150) } & & \\
\hline & Number & $\%$ & Number & $\%$ & & \\
\hline $\begin{array}{l}\text { Intrauterine device } \\
\text { Knowing } \\
\text { Not knowing }\end{array}$ & $\begin{array}{c}107 \\
43\end{array}$ & $\begin{array}{l}71.3 \\
28.7\end{array}$ & $\begin{array}{l}78 \\
72\end{array}$ & $\begin{array}{l}52.0 \\
48.0\end{array}$ & $\begin{array}{c}11.859 \\
\text { sd: } 1\end{array}$ & .001 \\
\hline $\begin{array}{l}\text { Birth control pill } \\
\text { Knowing } \\
\text { Not knowing }\end{array}$ & $\begin{array}{c}115 \\
35\end{array}$ & $\begin{array}{l}76.7 \\
23.3\end{array}$ & $\begin{array}{l}88 \\
62\end{array}$ & $\begin{array}{l}58.7 \\
41.3\end{array}$ & $\begin{array}{c}11.107 \\
\text { sd:1 }\end{array}$ & .001 \\
\hline $\begin{array}{l}\text { Condom } \\
\text { Knowing } \\
\text { Not knowing }\end{array}$ & $\begin{array}{c}105 \\
45\end{array}$ & $\begin{array}{l}\mathbf{7 0 . 0} \\
30.0\end{array}$ & $\begin{array}{c}116 \\
34\end{array}$ & $\begin{array}{l}77.3 \\
22.7\end{array}$ & $\begin{array}{c}2.079 \\
\text { sd:1 }\end{array}$ & .149 \\
\hline $\begin{array}{l}\text { Monthly/12-week injections } \\
\text { Knowing } \\
\text { Not knowing }\end{array}$ & $\begin{array}{c}47 \\
103\end{array}$ & $\begin{array}{l}31.3 \\
68.7\end{array}$ & $\begin{array}{c}26 \\
124\end{array}$ & $\begin{array}{l}17.3 \\
82.7\end{array}$ & $\begin{array}{c}7.984 \\
\text { sd:1 }\end{array}$ & .005 \\
\hline $\begin{array}{l}\text { Sub dermal implants } \\
\text { Knowing } \\
\text { Not knowing }\end{array}$ & $\begin{array}{c}25 \\
125\end{array}$ & $\begin{array}{l}16.7 \\
83.3\end{array}$ & $\begin{array}{c}8 \\
142\end{array}$ & $\begin{array}{c}5.3 \\
94.7\end{array}$ & $\begin{array}{c}8.716^{*} \\
\text { Sd:1 }\end{array}$ & .003 \\
\hline $\begin{array}{l}\text { Vasectomy } \\
\text { Knowing } \\
\text { Not knowing }\end{array}$ & $\begin{array}{c}28 \\
122\end{array}$ & $\begin{array}{l}18.7 \\
81.3\end{array}$ & $\begin{array}{c}18 \\
132\end{array}$ & $\begin{array}{l}12.0 \\
88.0\end{array}$ & $\begin{array}{c}2.080^{*} \\
\mathrm{sd}: 1\end{array}$ & .149 \\
\hline $\begin{array}{l}\text { Tubal ligation } \\
\text { Knowing } \\
\text { Not knowing }\end{array}$ & $\begin{array}{c}47 \\
103\end{array}$ & $\begin{array}{l}31.3 \\
68.7\end{array}$ & $\begin{array}{c}31 \\
119\end{array}$ & $\begin{array}{l}20.7 \\
79.3\end{array}$ & 4.435 & .035 \\
\hline
\end{tabular}

When the familiarity status of men and women with modern family planning methods for male and female were compared. It was found that there was significant difference women's knowledge on intrauterine devices, birth control pills, monthly/12-week injections and tubal ligation was significantly higher than male's $(p<0.05)$, (Table 2). We found that "it is more effective in preventing pregnancy when the experience increases with age" was significantly higher in man compared to women $(\mathrm{p}<0.05)$, (Table 3$)$. 
Table 3. Distribution of couples by sex regarding the use of withdrawal method $(\mathrm{N}=300)$

\begin{tabular}{|c|c|c|c|c|c|c|}
\hline \multirow{3}{*}{$\begin{array}{l}\text { Reasons for using withdrawal } \\
\text { method }\end{array}$} & \multicolumn{4}{|c|}{ Sex } & \multirow{3}{*}{$\chi^{2}$} & \multirow{3}{*}{$\mathrm{P}$} \\
\hline & \multicolumn{2}{|c|}{$\begin{array}{c}\text { Female } \\
\text { (n: 150) }\end{array}$} & \multicolumn{2}{|c|}{$\begin{array}{c}\text { Male } \\
\text { (n: 150) }\end{array}$} & & \\
\hline & $\mathrm{N}$ & $\%$ & $\mathrm{~N}$ & $\%$ & & \\
\hline $\begin{array}{l}\text { Easy-to-use } \\
\text { Yes } \\
\text { No }\end{array}$ & $\begin{array}{l}58 \\
92\end{array}$ & $\begin{array}{l}38.7 \\
61.3\end{array}$ & $\begin{array}{c}41 \\
109\end{array}$ & $\begin{array}{l}27.3 \\
72.7\end{array}$ & $\begin{array}{c}4.357 \\
\text { sd:1 }\end{array}$ & .037 \\
\hline $\begin{array}{l}\text { A reliable method } \\
\text { Yes } \\
\text { No }\end{array}$ & $\begin{array}{c}37 \\
113\end{array}$ & $\begin{array}{l}24.7 \\
75.3\end{array}$ & $\begin{array}{c}35 \\
115\end{array}$ & $\begin{array}{l}23.3 \\
76.7\end{array}$ & $\begin{array}{l}.073 \\
\text { sd:1 }\end{array}$ & .787 \\
\hline $\begin{array}{l}\text { My partner prefers it } \\
\text { Yes } \\
\text { No }\end{array}$ & $\begin{array}{l}59 \\
91 \\
\end{array}$ & $\begin{array}{l}39.3 \\
60.7\end{array}$ & $\begin{array}{c}40 \\
110\end{array}$ & $\begin{array}{l}26.7 \\
73.3\end{array}$ & $\begin{array}{c}5.442 \\
\text { sd: } 1\end{array}$ & .020 \\
\hline $\begin{array}{l}\text { Other methods involve costs } \\
\text { Yes } \\
\text { No }\end{array}$ & $\begin{array}{c}12 \\
138\end{array}$ & $\begin{array}{c}8.0 \\
92.0\end{array}$ & $\begin{array}{c}9 \\
141\end{array}$ & $\begin{array}{c}6.0 \\
94.0\end{array}$ & $\begin{array}{l}.205^{*} \\
\text { sd:1 }\end{array}$ & .651 \\
\hline $\begin{array}{l}\text { No side effects } \\
\text { Yes } \\
\text { No }\end{array}$ & $\begin{array}{l}69 \\
81\end{array}$ & $\begin{array}{l}46.0 \\
54.0\end{array}$ & $\begin{array}{l}71 \\
79\end{array}$ & $\begin{array}{l}47.3 \\
52.7\end{array}$ & $\begin{array}{l}.054 \\
\text { sd:1 } 1\end{array}$ & .817 \\
\hline $\begin{array}{l}\text { Other methods are religiously } \\
\text { objectionable } \\
\text { Yes } \\
\text { No }\end{array}$ & $\begin{array}{r}10 \\
140\end{array}$ & $\begin{array}{c}6.7 \\
93.3\end{array}$ & $\begin{array}{c}17 \\
133\end{array}$ & $\begin{array}{l}11.3 \\
88.7\end{array}$ & $\begin{array}{c}1.465^{*} \\
\mathrm{sd}: 1\end{array}$ & .226 \\
\hline $\begin{array}{l}\text { We want to have baby in a short time } \\
\text { Yes } \\
\text { No }\end{array}$ & $\begin{array}{c}27 \\
123 \\
\end{array}$ & $\begin{array}{l}18.0 \\
82.0\end{array}$ & $\begin{array}{c}28 \\
122 \\
\end{array}$ & $\begin{array}{l}18.7 \\
81.3\end{array}$ & $\begin{array}{l}.022 \\
\text { sd:1 }\end{array}$ & .881 \\
\hline $\begin{array}{l}\text { Because of health problems } \\
\text { Yes } \\
\text { No }\end{array}$ & $\begin{array}{c}23 \\
127\end{array}$ & $\begin{array}{l}15.3 \\
84.7\end{array}$ & $\begin{array}{c}12 \\
138\end{array}$ & $\begin{array}{c}8.0 \\
92.0\end{array}$ & $\begin{array}{c}3.235^{*} \\
\mathrm{sd}: 1\end{array}$ & .072 \\
\hline $\begin{array}{l}\text { It is more effective in preventing } \\
\text { pregnancy when the experience } \\
\text { increases with age } \\
\text { Yes } \\
\text { No }\end{array}$ & $\begin{array}{c}8 \\
142\end{array}$ & $\begin{array}{c}5.3 \\
94.7\end{array}$ & $\begin{array}{c}19 \\
131\end{array}$ & $\begin{array}{l}12.7 \\
87.3\end{array}$ & $\begin{array}{c}4.070 * \\
\text { sd: } 1\end{array}$ & .044 \\
\hline
\end{tabular}


Table 4. Opinions of couples on withdrawal method $(\mathrm{N}=300)$

\begin{tabular}{|c|c|c|c|c|c|c|}
\hline Opinions of couples regarding withdrawal method & Femal & : 150) & Male & (n: 150) & & \\
\hline Who prefers withdrawal? & $\mathrm{N}$ & $\%$ & $\mathrm{Nr}$ & $\%$ & $\chi^{2}$ & $\mathrm{P}$ \\
\hline My choice & 27 & 18.0 & 50 & 33.3 & & \\
\hline My wife's / husband's choice & 44 & 29.3 & 21 & 14.0 & 11.807 & 0.008 \\
\hline Both of us want to use that method & 76 & 50.7 & 76 & 50.7 & sd:3 & \\
\hline Family elders' decision & 3 & 2.0 & 3 & 2.0 & & \\
\hline $\begin{array}{l}\text { Having fear of becoming pregnant while using } \\
\text { withdrawal method }\end{array}$ & & & & & & 0.000 \\
\hline Yes & 63 & 42.0 & 25 & 16.6 & 28.779 & \\
\hline Sometimes & 35 & 23.3 & 73 & 48.7 & sd:2 & \\
\hline No & 52 & 34.7 & 52 & 34.7 & & \\
\hline $\begin{array}{l}\text { Opinions about becoming pregnant while using } \\
\text { withdrawal method }\end{array}$ & & & & & & 0.072 \\
\hline I will deliver/ I want her to deliver the baby & 95 & 63.4 & 80 & 53.3 & 7.007 & \\
\hline $\begin{array}{l}\text { I will have an abortion/ } \mathrm{O} \text { want her to have } \\
\text { abortion }\end{array}$ & 9 & 6.0 & 17 & 11.4 & sd:3 & \\
\hline I will discuss that with my & 35 & 23.3 & 32 & 21.3 & & \\
\hline not decided. not thought; (I will ask family elders') & 11 & 7.3 & 21 & 14.0 & & \\
\hline $\begin{array}{l}\text { Taking family planning training before deciding the } \\
\text { method }\end{array}$ & & & & & 10.092 & 0.001 \\
\hline Yes & 34 & 22.7 & 13 & 8.7 & sd:1 & \\
\hline No & 116 & 77.3 & 137 & 91.3 & & \\
\hline $\begin{array}{l}\text { The period they want to use withdrawal method } \\
\text { I will use permanently. } \\
\text { I will use for a short time } \\
\text { I do not want/ I will stop using }\end{array}$ & $\begin{array}{l}47 \\
86 \\
17\end{array}$ & $\begin{array}{l}31.4 \\
57.3 \\
11.3\end{array}$ & $\begin{array}{c}48 \\
98 \\
4\end{array}$ & $\begin{array}{r}32.0 \\
65.3 \\
2.7\end{array}$ & $\begin{array}{l}8.841 \\
\text { sd:2 }\end{array}$ & 0.012 \\
\hline $\begin{array}{l}\text { Psychological effect of the use of withdrawal } \\
\text { method }\end{array}$ & & & & & 13.133 & \\
\hline & 51 & 34.0 & 27 & 18.0 & sd:2 & 0.001 \\
\hline Sometimes & 48 & 32.0 & 45 & 30.0 & & \\
\hline No & 51 & 34.0 & 78 & 52.0 & & \\
\hline $\begin{array}{l}\text { Sex life being affected while using withdrawal } \\
\text { method }\end{array}$ & & & & & & \\
\hline No difference & 47 & 31.3 & 60 & 40.0 & 2.848 & 0.241 \\
\hline Being affected positively & 12 & 8.0 & 8 & 5.3 & sd:2 & \\
\hline Being affected negatively & 91 & 60.7 & 82 & 54.7 & & \\
\hline
\end{tabular}

It was understood from the study that there was a significant difference between men and women regarding preference of withdrawal method. (Having fear of becoming pregnant, their attitudes in case of an unwanted pregnancy and taking family planning training), (Table 4).

The rate of the individuals who did not have fear of becoming pregnant was

\section{Discussion}

When educational backgrounds of the men and women involved in our study were compared via Chi-Squared analysis, we found to be equal in both sexes. However, the ratio of women saying they were afraid of getting pregnant was higher than men.

When the duration of withdrawal use was examined, the rate of men and women using the method for 6-12 months were found to be $14.6 \%$, for $13-24$ months $24.0 \%$, 25-48 months $40.7 \%, 49$ months and over $20.7 \%$.

found no significant difference between men and women in terms of education $(\mathrm{p}<0.001)$.

According to 2008 Turkey Demographic and Health Survey, out as 
withdrawal known by nine out of every ten married women is still the most commonly known traditional method in Turkey. It was ascertained that one of every four married men and women in Turkey still use the withdrawal method. ${ }^{4}$

There was a statistically significant difference between men and women involved in the study in terms of knowledge status on the five modern family planning methods; intrauterine devices, birth control pills, monthly/12-week injections, sub dermal implants and tubal ligation $(\mathrm{p}<0.05)$. One could infer from this data that women have information about male-specific methods; however, men have a nodding acquaintance with female-specific methods. For this reason, wives and their husbands should be together in trainings covering effective family planning methods. By doing so, we can enhance men's knowledge on family planning methods and thus enable men and women to use modern contraceptive methods.

Another finding of our study was that, excluding the withdrawal method, the next mostly known method among male and female was the breastfeeding method. The rate of the women knowing with calendar and breastfeeding methods was found to be significantly higher statistically in women compared to men $(p<0.01)$. These results indicate that although men and women were familiar with effective Family Planning methods, they insisted on using the methods with limited effect.

When a literature review was conducted, it was found that there were several reasons for men and women to choose o withdrawal as a birth-control method: for instance, reliability, not having knowledge on other methods, economical (low cost), no side effects, preferences of partners, easy-to-use characteristic, no hormonal content, religious beliefs and etc. $^{9,10}$

Studies indicated that $39.4 \%$ of women use the out as withdrawal method due to their husbands' request. ${ }^{11,12}$
Güngör et al. evaluated the contraception methods used by women and indicated that out as withdrawal was the most frequently used method. ${ }^{13}$

The reasons of the men and women for using the withdrawal method were compared, the rate of women stating that they preferred the withdrawal method because it was easy to practice or their partners preferred it was statistically significantly higher women compared to men $(\mathrm{p}<0.05)$. Men who stated that they were using that method as it became more successful in preventing pregnancy with experience and age was statistically significantly higher in men compared to women $(p<0.05$, Table 3$)$. The results of the study have parallels with the literature. Studies conducted earlier determined that men and women prefer using traditional methods because of fallacies against modern family planning methods. ${ }^{12,14}$

When we analyzed the reasons for using out as withdrawal, we witnessed that women mostly said they had made the decision together with their partners, while most of the men said it was "their choice". That fact indicates that while making a decision on contraception women ask their partners' opinion, the majority of men made decisions by themselves. Therefore, we can infer from this information that men take a more active role in the use of the withdrawal method and it is a male-oriented preference method.

As indicated by several studies, the most important factor why women prefer in a family planning method is its reliability. However, it is interesting that women deferred to the man's request as their reason to use the withdrawal method. It was found that factors such as manhood stunt gender ability, indicator of youthfulness etc. influenced men to choose the withdrawal method. $^{15}$

Family planning services mainly focus on women and men are generally ignored by health service providers.

One of the important facts obtained from the study is that although women were 
worried about becoming pregnant while using the withdrawal method, they continue using the method due to their husbands' demand. When men and women were asked what they would do if a pregnancy status occurred while using the withdrawal method, more than half of the women and men gave the answer "I will deliver/ I want her to deliver the baby". It was found that there was a significant difference between men and women regarding anxiety for becoming pregnant $(\mathrm{p}<0.001)$.

Women are correct to fear becoming pregnant because, according to study results, pregnancy rate is high in women who use the withdrawal method. Çiftçioğlu found pregnancy rate during out as withdrawal used to be $27.5 \%$ in her study, while Y1ldırım in his study stated it as $28.6 \% .^{16,17}$

It is also thought-provoking that although most of the men and women participating in the study had reported that they did not want to have another baby, they were determined to deliver the baby in case of an unwanted pregnancy while using the withdrawal method, which is not an effective birth-control method. Furthermore, the withdrawal method is a long-term correct adjective method which is used regardless of the opportunity to access modern contraceptive methods. $^{18,19}$

It was indicated in many studies that the withdrawal method is still regarded as an effective family planning method and, even if it leads to unwanted pregnancies there is no change in the attitudes and behaviors of families towards the method. ${ }^{20,21}$

While the withdrawal method is an ineffective method, it is frequently used due to several cultural and personal reasons while more effective methods have a low usage rate. That situation increases the unwanted pregnancy rate of women and thus causes women to end their pregnancy with abortion. ${ }^{22}$ Contradicts the tests done in this report Despite the fact that unintended pregnancies terminate with miscarriages in Turkey, there is not a significant decrease in the use of as the withdrawal method. ${ }^{4}$
Our study indicated that the ratio of women taking family planning training was significantly higher compared to men $(\mathrm{p}<0.01)$. When they were asked how long they wanted to use the withdrawal method, there was a significant difference between the answers of men and women $(p<0.05)$. It was also found in the study that the rate of women expressing that they do not want to use/ want to stop using the withdrawal method is significantly higher than men $(\mathrm{p}<0.05)$.

The study showed that permanent use of the withdrawal method caused sexual dissatisfaction and psychological tension in men and women. ${ }^{16}$ The withdrawal method requires a man, during intercourse, to withdraw his penis from a woman's vagina prior to orgasm. However, it is not easy for the man to use this method effectively as it can result in unwanted pregnancies and dissatisfied sexual intercourse. ${ }^{23}$

In the study conducted by Kıliç et al. women expressed that their sexual lives were negatively affected by the use of the withdrawal method. However, they could ignore effects of a contraceptive method and tolerate it as long as it provided protection from pregnancy. ${ }^{24}$

The study also indicated that there was no significant difference between men and women regarding being sexually affected by the use of the withdrawal method ( $p>0.05)$, but the difference between men and women was significant when the psychological influence of the method came into question $(p<0.01)$. The rate of men who were not affected psychologically was found to be significantly higher than women. Although it was found in the study that out as withdrawal affected men and women' sexual life negatively, they still continued using that method for preventing pregnancy. Therefore, the decision-making process on effective methods for healthy marriages and sexual life should be facilitated for men and women.

\section{Conclusion}


The withdrawal method was preferred mostly by male and female were using the method as their husbands wanted it. Those males and females who were using the withdrawal method as their most preferred method were doing so as it was the choice of the male. It this preference was also significantly higher in men compared the women $(p<0.05)$. The reasons for using the withdrawal method were found to be, respectively, not having side effects, being easy to practice, being a reliable method and partner's request.

\section{References}

1. Finger WR. Withdrawal popular in some culteres. Contraceptive Update Network 1996; 17: 15- 16.

2. Koyuncuer E. Kontrasepsiyon ve Türkiye'de durum [Contraception and the status of Turkey]. Sted 2004;13: (12), 455459.

3. Mehryar AH, Mostafavi F, Agha H. Men and family planning in iran. The IUSSP XXIVth General Population Conference in Salvador de Bahia, Brazil, Augus 2001; t 1824, 4.

4. Türkiye Nüfus ve Sağlık Araştırması Ana Rapor (TNSA 2008). [Turkey Population and Health Research (TDHS2008)]. Accession date: 15.03.2011. http://www.hips.hacettepe.edu.tr/TNSA2008 -AnaRapor.pdf (2010).

5. Ersin F, Gözükara F, Şimşek Z, Kayahan Kurçer MA. Bir sağlık ocağ 1 bölgesindeki kadınların aile planlaması yöntemlerini kullanma durumları ve yöntem birakma nedenleri. [He stuation of the contraceptive use and the reasons of family planning method discontinuation of married women in a primary health care center area].Hemşirelikte Araştırma Geliştirme Dergisi 2003; 1: 30-37.

6. Ulusal Anne Ölümleri Çalışması (2005). [National maternal mortality study]. Hacettepe Üniversitesi Nüfus Etütleri Enstitüsü SB Ana-Çocuk Sağlığı ve Aile Planlamas1 Genel Müdürlüğü, Avrupa Birliği Komisyonu Türkiye Delegasyonu Ankara.
7. Ulusal Aile Planlaması Hizmet Rehberi (2005). [National family planning and service guide],T.C. Sağlık Bakanlığı Ana Çocuk Sağlığı ve Aile Planlaması Genel Müdürlüğ̈̈,Cilt, 2.

8. Apay SE, Pasinlioğlu T. Nişanlı çiftlerin evlendikten sonra kullanmay1 düşündükleri aile planlaması yöntemleri. [Family planning methods engagedcouples thought to use after marriage]. Atatürk Üniversitesi Hemşirelik Yüksekokulu Dergisi 2008;11: 4 [Journal of Ataturk University School of Nursing]

9. Atış F, Yurdakul M, Öztürk M, Karaman M. Koitus interruptus kullanım nedenleri ve yöntem başarısını etkileyen faktörler. [The reasons for using the koitus interruptus method and the factors affecting the success of it]. Firat Sağllk Hizmetleri Dergisi 2010; 5: (15), 31-44.

10. Doğan G. Kontrasepsiyon amaçlı başvuran kadınların erkek kontrasepsiyonuna bakış açısı. [Perspective on male contraception contraception in women attending purpose]. Afyon Üniversitesi Sağllk Bilimleri Enstitüsü Kadın Hastalıklarl ve Doğum Hemşireliği Yüksek Lisans Tezi 2008; Afyon.

11. Family Planning Unmet Need Analyzed. Population Today 1997; 1: 3-25.

12. Yanıkkerm E, Acar H, Elem E. Withdrawal users' persceptions of and experience with contraceptive methods in manisa,Turkey. Midwifery 2006; 22 : 274-284.

13. GüngörS, Başer I, Göktolga U, Özkömür E, Keskin U. Koitus interruptus (geri çekme) yönteminin etkinliği ve eğitim seviyesinin önemi. [ Efficacy of withdrawal method and the importance of education level]. Gülhane Tip Dergisi 2006; 48 (1),8-10.

14. Yurdakul M, Vural G. Reasons for using traditional methods and role of nurses in family planning science direct: contraception 2002. Accession date: 14.07.2009. htpp ://www.sciencedirect.com/science ? 
_ob=ArticleURL\&_udi=B6T5P-

4602RF0-7\&_user $=74727 \&$ \&.

15. Ortaylı,N, Bulut A, Özgürlü M, Cokar M. Why Withdrawal? Why Not Withdrawal? Mens Perspectives. Reprod Health Matters 2005; 13: (25), 164-73

16. Çiftçioğlu S. Geri çekmenin aile planlaması yöntemi olarak kullanılma nedenleri. [Reasons to be used as a method of family planning to withdraw]. Atatürk Üniversitesi Sağllk Bilimleri Enstitüsü Halk Să̆lı̆̆ Hemşireliği Anabilim DALI, Yüksek Lisans Tezi 2006; Erzurum.

17. Yıldırım B. Göztepe Eğitim Araştırma Hastanesinde İsteyerek Doğum Yapmış Kadınların Sosyodemografik Özellikleri ve Aile Planlaması Bilgi Düzeylerinin Karşılaştırılması.[Socio-demographic characteristics of goztepe training and research hospital for women and family planning information induced births levels]. Uzmanlık Tezi, İstanbul 2008.

18. Miller R.. Withdrawal: A very great deal better than nothing. Canadian Journal of Human Sexuality 2003;12: 189-190.

19. Horner JR, Salazar LF, Romer D et al. "Withdrawal (coitus interruptus) as a sexual risk reduction strategy: perspectives from African-American adolescents," Archives of Sexual Behavior 2009; 38: (5), 779-787.
20. İnce N, Özyıldırım BA, Ozden Irmak Y. The use the family planning methods in one administrative of istanbul. The European Journal of Contraception and Reproductive Health Care 2003; 8: 2126.

21. 21.Ünsal A, Öner SD, Nuhoğlu S, İnan O, Metintaş S.Eskişehir'den15-49 yaş grubunda evli kadınların aile planlaması ile ilgili bilgi, tutum ve davranışları. [Eskişehir married women 15-49 age group related to family planning knowledge, attitude and behavior]. Klinik Bilimler ve Doktor 1999; 5:36-41.

22. Şahin S, Cevahir R, Sözeri C. Sakarya doğum ve çocuk bakımevi hastanesi ne isteğe bağlı kürtaj için başvuran kadınların değerlendirilmesi. [Sakarya maternity and child care hospital assessment of women attending for abortion optional].Firat Sağlık Hizmetleri Dergisi 2003;1: 1.

23. Withdrawal Coitus Interruptus). (Accession date: 22.06.2010, htpp://meshealth.about.com/od/contracep tion/a/coitus.htm. [in Turkish].

24. Kılıç A, Akyüz A, Yavan T, Güvenç G. Kontraseptiflerin cinsel yaşantıya etkileri üzerine niteliksel bir çalışma.[A Qualitative study on the effects of contraceptives sexual normal life].Türkiye Klinekleri JinekolojiObstetrik Dergisi 2003;19:(3),131-141. 